\title{
Organizational Culture and Job Satisfaction in Bank: Perceptions and Reactions of Employees
}

\author{
Md. Abdul Hakim*
}

Assistant Professor, School of Business, Asian University of Bangladesh, Uttara, Dhaka, BANGLADESH

*Corresponding Contact:

Email: hakimmbarubd@yahoo.com

Cell Phone: +8801714231003

\begin{abstract}
This study examines employees' perceptions and reactions regarding the organizational culture for their job satisfaction where the five variables or organizational culture are selected as working conditions, compensations, respect from co-workers, relationships with supervisors and opportunity for advancement. The key purpose of this study effort was to investigate how organizational culture can affect job satisfaction of the employees in response their perceptions and reactions towards the organizational culture factors. This study operationally defined culture in terms of working conditions, compensations and benefits, respect from co-workers, relationships with supervisors and opportunity for advancement. To this research, both primary and secondary data are used where the statistical population included the employees of bank organizations in Bangladesh. Almost primary based, the data were collected through the distribution of a standardized questionnaire among 500 employees through convenience sampling. This study revealed that Respects from the co-workers as the components of organizational variable has the most domination in framing Job Satisfaction in respect of the employees perceptions of the bankers where working conditions has the least among five explanatory variables. The statistical result of this paper also found that the selected organizational culture related variables have the direct effect over the level of job satisfaction to either increase or decrease. The results of this study supported the reliability measures of the organizational culture questionnaire over the populations, regardless of the reality that the sample size for this study was inadequate. A further suggestion for future research would be to establish whether improving measurement and response mechanisms in the jobs of social workers would positively influence job satisfaction and perception of organizational culture by employees in this job category.
\end{abstract}

Key Words: Organizational Culture, Job Satisfaction, Bank Organization, NPL, NPSB

\section{INTRODUCTION}

The economy and the economic trend of Bangladesh in 2014 is seen upwards direction despite of some unexpected worries where the economy of Bangladesh has registered a balanced increase of greater than $6 \%$ in the last couple of years. 
The political pandemonium in 2013 and 2014 produced timid business atmosphere for setting up new industries consequential in downwards investment demand that led to glut liquidity in the banking system. However, the economy of Bangladesh started to obtain in force during the year under review. In fact, the economy of Bangladesh achieved a decent $6.12 \%$ growth rate against all odds that was $6.00 \%$ during 2013. There was a breath of fresh air as inflation was at a comfortable level. Particularly to mention that point to point inflation in December 2014 was 6.11\% (lowest in 25 months) whereas in December 2013 it was 7.35\%. The country's overall import increased by $11.36 \%$ to US $\$ 16.20$ billion during July-November of fiscal year 2014-2015 mainly due to higher import of fuel oils and capital machinery. Export earnings in the first half of fiscal 2014-15 stood at US \$14.91 billion, a slight improvement by $1.56 \%$ yearon-year. The country's overall remittance inflow increased by $7.90 \%$ to US $\$ 14.92$ billion in 2014 in comparison to US $\$ 13.83$ billion in 2013. Country's Trade Balance in July-August of fiscal year 2014-15 showed a negative US \$999 million, which was negative US \$790 million in the corresponding period of the previous year (Bangladesh Bank Statistics, 2014-2015). On the other hand the Current Account Balance shows a negative US \$1,261 million but a huge financial account surplus resulted in a positive $\$ 1,246$ million in the overall balances in July to October 2014 period. The foreign currency reserve stood at $\$ 22.30$ billion in December 2014, a record until the study period. Credit to private sector registered $12.27 \%$ growth against the target of $14.50 \%$ in the fiscal year 2013-2014. NPL, the much talked about issue in the banking area, was $4.27 \%$ in September 2014 compared to 2.01\% in December 2013. The statements that have been mentioned here in order to know the contribution of the banking section of Bangladesh to the economy of Bangladesh and the economic trends where a bank is an establishment whose existing operation consists in conceding loans and receiving deposits from the public. In figure, there are about 6 state-owned commercial, 2 state-owned specialized, 31 private commercial, 8 private Islamic commercial, 9 foreign commercial, 10 specialized and 40 NPSB members banks organizations are doing their business by providing financial services in Bangladesh (Bangladesh Bank Periodic, September, 2015). A massive number of employees are serving in the bank companies in Bangladesh where the performance of the employees sturdily makes impact on the success of bank business. Along with this, the contribution of the employees towards the successful running of the bank business depends on their job satisfaction. Besides, organizational culture is one of the most significant forces that create job satisfaction or dissatisfaction. This research work has been conducted to know the relationships between the organizational culture and job satisfaction of the employees where the study field is bank organization. The study is done by using both primary and secondary data based on field works on 500 employees in different types of banks at Dhaka City in Bangladesh. The determinants that are used as organizational culture to test the job satisfaction of the employees measuring their perceptions and reactions are assumed as the variables such as working conditions, compensations, respect from co-workers, relationships with supervisors and opportunity for advancement. The surveyed organizations and their cultures and the demands of job satisfaction in response of the perceptions and reactions of the employees of bank organizations may lead to a conflict situation. This leads to the question: what determinants of organizational culture have the strong influence on stimulating and promoting the job satisfaction in organization?

\section{CONCEPTUAL FRAMEWORK}

In definition, organizational culture is defined as shared philosophies, ideologies, values, assumptions, beliefs, expectations, attitudes and norms in organizations (Lund, 2003; Maslowski, 2001). It is a pattern of shared basic assumptions and is developed over time as people in the organization learn to deal with problems of external adaptation and internal 
integration (Schein, 1999). Besides, Locke (1969) defined job satisfaction as an emotional state related to the positive or negative appraisal of job experiences. Kreis and Brockopp (1986) suggested that job satisfaction "is related to self-perception of needs fulfillment through work." Pennington and Riley (1991) contemplated a outlook of job satisfaction as an external or internal value. In their view, a person's general assessment of how satisfied he/she is on the job is made according to an absolute frame of reference, while an employee's assessment of level of satisfaction with individual job facets is based on a relative standard that is specific to the work context and that involves comparison with the situation of other employees. Weiss and Cropanzano (1996, as cited in Thoms, Dose, and Scott, 2002), contended that "job satisfaction represents a person's evaluation of his or her job and work context." Job satisfaction is known as a construct which comprise of the employee feelings about different job element. In this era of industry and investment, the market has become much more competitive and volatile. A certain type of culture has grown in the organizations indicating the type of their strategies and work procedure. Employees in the concerned organizations become a part of that culture. The recent worldwide financial crisis has affected the global market to a great deal. Such turbulence has made employees anxious, disappointed and has inculcated in them an aggressive behavior. They have developed some sort of negative attitude towards their organization as well as their job. They have become less committed and less transparent. Hence it has become very essential for the management to turn to human resource management and help employees to be satisfied with their job not only to retain them but to incorporate in them a strong sense of involvement that would sure drive the business performance. Here the role of organizational culture comes into play. In such a strong culture employees reflect a pride of ownership throughout the company and workforce wide understanding of the company's strategic goals. Such a culture encompasses the collective goals of a company and the standards of expected behavior in achieving these goals (Biswas, W., 2015, p. 15). With the great number of organizations and institutions globally, it is only natural that the general well-being of workplaces has become an object of theoretical interest and extensive research. An organization's well-being is described as the way in which its function and quality are perceived by employees (Warr, 1992). It includes the employees' physical and mental health, sense of happiness and social well being, which are all attributed with the term "job satisfaction" (Grant et al., 2007).

\section{LITERATURE REVIEW}

Review of literature is an integral part of conducting research. Review of past literature helps conceptualization, formulation of hypotheses and choice of tools of analysis. It also helps in arriving at meaningful conclusions. In almost any organization around the globe, the organizational culture would consist of the uniquely patterned beliefs, feelings, values and behavior that connect the members to the organization and simultaneously distinguish that organizational culture from the cultures of other organizations. With this view a brief review of past studies and concepts relevant to the present study are highlighted in below.

Arnold \& spell, 2006 showed in their research work that employees' benefits and rewards constitute $30-40 \%$ of the compensation package of the employees which is often overlooked by the management. Seashore and Taber (1975) claimed that rewards and benefits have a positive impact on the job satisfaction of the employees. Identified that job rewards can be used as the tools for improving the financial situation have a strong impact on the job satisfaction.

Bellou, 2010 has examined organizational culture relation on job satisfaction regarding with the gender and age. Result suggests that some cultural types effect on employees job satisfaction they may be personal growth opportunities, good reputation. Recommendations 
according to this research are organizational culture can enhance employee's job satisfaction to feel them part of the organization and encourage them to build their career within and outside organization, because if organization bound their employees to built and enhance their capabilities and expertise within organization they may be not fully show their capabilities, in this way organization don't have chance to lose their employee and their loyalty towards organization and that become organizational competitive advantage.

Jiang \& Klen, 2000, said in their paper that in the past decades it has been clearly identified that supervisors support can create the positive impact in the job satisfaction of the employees (Greenhaus,1990) supervisor support can be taken as the positive support by the supervisors for the career development of the subordinates (Kram,1985). It has been observed that higher level of the supervisor support increases the job satisfaction which in turn decreases the turnover rate.

Jung et al, 2008 has explored the relation between organizational cultures from national culture on total quality management performance. About 186 multinational organizations filled questionnaire, regression analysis shows that total quality management is significant relates with organization culture and total quality management has positive impact on business performance.

Mckinnon, 2003 told that obviously, cultural dimensions are reflected in various forms in the external life of a society or an organization, as well as in the values and beliefs held by its members. Culture; have been under consideration from the aspect of its different dimensions playing a role in effecting the job satisfaction.

Palthe \& Kossek, 2003 however, it was also claimed that perception about the organization culture can never be the same among all the employees and it varies from person to person depending upon their own beliefs and mind sets.

Rashid et al, 2004 have studied organizational culture and organizational changes in Malaysia. Finding shows that association between organizational cultures, effectiveness attitude of organizational changes, result also shows that different types or organizational culture have their own way for the acceptance in organizational changes. This means every organizational culture has some capabilities for the changes and some organization does not allow their employees to change with the external environment, not even try to change their culture with time.

Wallach, 1983 has argued that grouped organizational culture becomes three, that is: bureaucracy culture, innovative culture and supportive culture. (1) Bureaucracy culture is culture hose condition needs arrangement, command and rules (2) innovative culture bring freedom to participant in it to free in thinking, stating opinion, free their thought and feeling and to work (3) supportive culture is in its communication interaction give emphasis to the kinship values such as harmony, openness, friendship, cooperation, and trust.

\section{RATIONALE OF THE STUDY}

The satisfied employee brings prosperity for the organizations, managers, shareholders and other stakeholders of any business. Eagerness to make available excellence services in today's globe plays a significant task in the service industries. Since service excellence is considered vital for organization's survival and profit making. Service excellence plays a considerable role in customer's satisfaction, maintenance, and stability. A lot of experts began to bicker that budding a strong organizational culture is crucial for success. Management should meet up the desires and needs of internal customers so that the staffs have towering levels of 
satisfaction and give high class external service to external customers. It does not come as a surprise that employees experience work-overload and underpay, develop competitive relationships with colleagues and superiors and get involved in strike actions. Therefore, employees' preferences should be measured, studied and utilized both in the frame of the specific organization they work in and in the frame of branches and national cultures, as promoting employee's well being has been found to improve their performance and productivity and make organizations competitive. This paper studies the role of organization's culture on the job satisfaction in respects of perceptions and reactions of the employees belonging to the banks in Bangladesh. This study will be of great benefit to the management, policy makers, researchers and others.

\section{LIMITATIONS OF THE STUDY}

This research has some limitations and future work can be done. Due to lack of time of the researchers, the study has been done on 500 sample size from a huge population over the surveyed field. This research was conducted mostly in a quantitative way. It will be better to continue some qualitative research and make comparison between qualitative and quantitative results to know the accurate rationality of the selected topic and the comparison fields. At the time of collecting data from the sample, the employees were too busy at their works to provide optimum time to conduct the research. Moreover, the top level management and the concerned branch authority sometimes seemed reluctant to provide required information. Considering of all the limitations of this study, the researcher thinks that in future it will be convenient for the researchers to deal with any gap derived from this study.

\section{Purposes ANd ObJectives of The Study}

The key objective of this study was to investigate the impact of organizational culture on job satisfaction of the employees in relation to their perceptions and reactions their work place. The specific objectives of the study were:

- To describe demographic characteristics of the respondents.

- To identify determinants of organizational culture have the strong influence on stimulating and promoting the job satisfaction in organization.

- To analysis the nature of perception of the employees towards their job supporting activities.

- To assess the relationships among the variables of organizational culture and job satisfaction of the employees of Bank Organizations.

- To offer suitable suggestions on the basis of the study.

\section{HYPOTHESIS OF THE STUdY}

The hypotheses for this study have been drawn as;

$\mathrm{H}_{\mathrm{a}}$ : The determinants of organizational culture have the impact on employees' job satisfaction.

$\mathrm{H}_{\mathrm{o}}$ : There is no relationship between the determinants of organizational culture and the employees' job satisfaction.

\section{Methods and Materials}

The study is explanatory as well as descriptive in nature and based on both primary and secondary data. The sample population for this study was composed of the employees of the banks in Bangladesh. Primary data are collected through the questionnaire and interviews, 
and secondary data are collected from annual reports, periodic, journals, magazines and books. The study is done using the convenience sampling where the researchers issued five hundred and fifty (550) questionnaires to the selected employees from top level to bottom of selected State-owned Commercial, State-owned Specialized, Private Commercial, Private Islamic Commercial, Foreign Commercial, Specialized and NPSB members banks at Dhaka City in Bangladesh and out of which five hundred (500) were returned with their responses. The selected organizations with the surveyed sample size are mentioned in below:

Table 1: Sample distribution

\begin{tabular}{|c|c|c|c|}
\hline Name of Banks & Sample Size & $\%$ & Total \\
\hline State-owned Commercial: & \multirow[b]{2}{*}{30} & \multirow[b]{2}{*}{$6 \%$} & \\
\hline Sonali Bank Limited & & & \\
\hline Janata Bank Limited & 30 & $6 \%$ & $12 \%$ \\
\hline State-owned Specialized: & \multirow[b]{2}{*}{30} & \multirow[b]{2}{*}{$6 \%$} & \\
\hline Bangladesh Krishi Bank Limited & & & $6 \%$ \\
\hline Private Commercial: & \multirow[b]{2}{*}{30} & \multirow[b]{2}{*}{$6 \%$} & \\
\hline Dhaka Bank Limited & & & \\
\hline Dutch Bangla Bank Limited & 30 & $6 \%$ & \\
\hline Jamuna Bank Limited & 30 & $6 \%$ & \\
\hline Mercantile Bank Limited & 30 & $6 \%$ & \\
\hline National Bank Limited & 30 & $6 \%$ & \\
\hline Prime Bank Limited & 30 & $6 \%$ & \\
\hline Southeast Bank Limited & 30 & $6 \%$ & \\
\hline United Commercial Bank Limited & 30 & $6 \%$ & $48 \%$ \\
\hline Private Islamic Commercial: & \multirow[b]{2}{*}{30} & \multirow[b]{2}{*}{$6 \%$} & \\
\hline Islami Bank Bangladesh Limited & & & \\
\hline Al-Arafah Islami Bank Limited & 30 & $6 \%$ & \\
\hline Shahjalal islami Bank Limited & 30 & $6 \%$ & $18 \%$ \\
\hline Foreign Commercial: & \multirow[b]{2}{*}{20} & \multirow[b]{2}{*}{$4 \%$} & \\
\hline Standard Chartered Bank & & & \\
\hline Citibank NA & 20 & $4 \%$ & $8 \%$ \\
\hline Specialized: & \multirow[b]{2}{*}{20} & \multirow[b]{2}{*}{$4 \%$} & \\
\hline Karmasangsthan Bank & & & \\
\hline Grameen Bank & 20 & $4 \%$ & $8 \%$ \\
\hline Total & 500 & & $100 \%$ \\
\hline
\end{tabular}

Questionnaire is designed to gather the data consisting two parts where Part-I designed as the demographic characteristics of the respondents includes age, gender, educational qualification etc while Part-II consists 30 statements to measure the job satisfaction in relation to organizational culture including five dimensions such as working conditions, compensations and benefits, respect from co-workers, relationships with supervisors and opportunity for advancement. The collected data regarding the employees perceptions and reactions are analyzed through descriptive statistics using SPSS; analysis of the forces under the variables using central tendency and dispersion statistics and testing the employees job satisfaction through the correlation matrix, ANOVA and the simple statistical tools. The analysis has been done using the Likert five points scale such as $1=$ =strongly agree, $2=$ agree, $3=$ somewhat agree, $4=$ disagree and $5=$ strongly disagree. 


\section{ANALYSIS AND INTERPRETATION}

\section{Biographic Variables of the Employees}

The table 2 shows the distribution of respondents according to biographic variables where age, gender, educational qualification, working experience of the respondents are mentioned along with their feelings towards their respective organizations. The age of the respondents are classified into 7 stages where 25 year start and end to the more than 55 years. Among the 500 employees most of the employees are belongs to the age of 25 to 30 years (21.4\%), followed by 30 to 35 years $(18.2 \%)$ and employee belongs to more than 55 years is $4.6 \%$ are the most senior persons. From the gender views major of the employees are male that is $63 \%$ and the rest $17 \%$ belongs to female. The educational qualification of the respondents or the employees of the selected banks organizations is distributed into 6 categories starts from under SSC and end to the higher education that is $\mathrm{PhD}$ or M.Phil. Most of the employees $79 \%$ doing their job with the post graduation degree followed by $10.40 \%$ belong to graduate degree. Only $2.0 \%$ employees have done their higher education as well there is no employee belongs to under SSC. Besides the working experience of the employees are not avoidable. About $22.40 \%$ of the employees belong to the experience of less than 5 years followed by $14.29 \%$ and $20.20 \%$ of the employee is in the range of 15 to 20 years experience. In the distribution table about $92 \%$ employees are well known about the mission of the organization and $99.80 \%$ agree with that mission. Moreover, about $89.0 \%$ employees think that they are the integral part of the organization.

Table 2: Distribution of Respondents According to Biographic Variables

\begin{tabular}{|c|c|c|}
\hline Particulars & $\mathrm{N}$ & $\%$ \\
\hline \multicolumn{3}{|c|}{ Respondents' Age } \\
\hline 25 to 30 Years & 107 & 21.4 \\
\hline 30 to 35 Years & 91 & 18.2 \\
\hline 35 to 40 Years & 82 & 16.4 \\
\hline 40 to 45 Years & 80 & 16 \\
\hline 45 to 50 Years & 68 & 13.6 \\
\hline 50 to 55 Years & 49 & 9.8 \\
\hline More than 55 Years & 23 & 4.6 \\
\hline Total & 500 & $100 \%$ \\
\hline \multicolumn{3}{|c|}{ Respondents' Gender } \\
\hline Female & 185 & 37 \\
\hline Male & 315 & 63 \\
\hline Total & 500 & $100 \%$ \\
\hline \multicolumn{3}{|c|}{ Respondents' Educational Qualification } \\
\hline Under SSC & 0 & 0 \\
\hline SSC & 25 & 5 \\
\hline HSC & 18 & 3.6 \\
\hline Graduate & 52 & 10.4 \\
\hline Post Graduate & 395 & 79 \\
\hline Upper Post-Graduation & 10 & 2 \\
\hline Total & 500 & $100 \%$ \\
\hline \multicolumn{3}{|c|}{ Respondents' Working Experience } \\
\hline Less than 5 Years & 112 & 22.4 \\
\hline
\end{tabular}




\begin{tabular}{|c|c|c|}
\hline 5 to 10 Years & 98 & 19.6 \\
\hline 10 to 15 Years & 101 & 20.2 \\
\hline 15 to 20 Years & 72 & 14.4 \\
\hline 20 to 25 Years & 54 & 10.8 \\
\hline 25 to 30 Years & 29 & 5.8 \\
\hline More than 30 Years & 34 & 6.8 \\
\hline Total & 500 & $100 \%$ \\
\hline \multicolumn{3}{|c|}{ Respondents' Known about the Organization Mission } \\
\hline Yes & 460 & 92 \\
\hline No & 5 & 1 \\
\hline Little Bit & 35 & 7 \\
\hline Total & 500 & $100 \%$ \\
\hline \multicolumn{3}{|c|}{ Respondents' Agree with the Mission of the Organization } \\
\hline Yes & 499 & 99.80 \\
\hline No & 0 & 0.0 \\
\hline Little Bit & 1 & 0.20 \\
\hline Total & 500 & $100 \%$ \\
\hline \multicolumn{3}{|c|}{ Respondents' Feeling as Organizational Part } \\
\hline Yes & 445 & 89.0 \\
\hline No & 10 & 2.0 \\
\hline Little Bit & 45 & 9.0 \\
\hline Total & 500 & $100 \%$ \\
\hline
\end{tabular}

Source: Field Work

Result of Descriptive Statistics of the Job satisfaction Perceptions of the Employees

Table 3: Descriptive Statistics on the Job Satisfaction Perceptions Survey in Relation to Organizational Culture $(\mathrm{N}=500)$

\begin{tabular}{|c|c|c|c|c|c|c|c|c|c|}
\hline \multirow[t]{2}{*}{ Working Conditions } & \multicolumn{2}{|c|}{ Mean } & S.D. & Var. & \multicolumn{2}{|c|}{ Skew. } & \multicolumn{2}{|c|}{ Kurt. } & \multirow[b]{2}{*}{$\mathbf{R}$} \\
\hline & Stat. & SE & Stat. & Stat. & Stat. & SE & Stat. & SE & \\
\hline Relationships with Subordinates & 1.22 & .046 & .46 & .21 & 1.9 & .241 & 3.2 & 478 & 1 \\
\hline Relationships with Co-Workers & 1.26 & .044 & .44 & .19 & 1.1 & 241 & -.7 & 478 & 2 \\
\hline Relationships with Supervisor(s) & 1.37 & .051 & .50 & .25 & .7 & .241 & -.8 & 478 & 3 \\
\hline Communication from Employees to Managers & 1.64 & .056 & .55 & .31 & .1 & 241 & -.7 & .478 & 4 \\
\hline Tools and Resources need to Do Job & 1.72 & .062 & .62 & .38 & .2 & .241 & -.6 & .478 & 5 \\
\hline Communication from Managers to Employees & 1.82 & .046 & .45 & .21 & -.6 & .241 & .6 & .478 & 6 \\
\hline $\begin{array}{l}\text { Adequate Opportunity for Periodic Changes in } \\
\text { Duties }\end{array}$ & 2.06 & .049 & .48 & .23 & .1 & .241 & 1.2 & .478 & 7 \\
\hline Degree of Independence Associated with Work Roles & 2.66 & .048 & .47 & .22 & -.6 & 241 & -1.5 & 478 & 8 \\
\hline Satisfactory Work Load & 2.88 & .059 & .59 & .34 & -.2 & 241 & .6 & .478 & 9 \\
\hline Stress Feelings & 3.38 & .063 & .63 & .40 & -.2 & 241 & -.4 & .478 & 10 \\
\hline
\end{tabular}




\begin{tabular}{|c|c|c|c|c|c|c|c|c|c|}
\hline \multirow[t]{2}{*}{ Compensation and Benefits } & \multicolumn{2}{|c|}{ Mean } & S.D. & Var. & \multicolumn{2}{|c|}{ Skew. } & \multicolumn{2}{|c|}{ Kurt. } & \\
\hline & Stat. & $\mathrm{SE}$ & Stat. & Stat. & Stat. & $\mathrm{SE}$ & Stat. & $\mathrm{SE}$ & $\mathrm{R}$ \\
\hline Arrangement of Fringe Benefits & 1.60 & .056 & .56 & .32 & .2 & 241 & -.7 & .478 & 1 \\
\hline Satisfactory Salary & 1.91 & .042 & .42 & .18 & -.5 & 241 & 2.2 & .478 & 2 \\
\hline Job Security & 2.84 & .05 & .50 & .25 & -.2 & 241 & .4 & .478 & 3 \\
\hline Recognition for Work Accomplished & 3.02 & .04 & .42 & .18 & .1 & 241 & 2.7 & .478 & 4 \\
\hline Fair Opportunity For Promotion & 3.03 & .05 & .55 & .31 & -.3 & 241 & 1.6 & .478 & 5 \\
\hline
\end{tabular}

\begin{tabular}{|c|c|c|c|c|c|c|c|c|c|}
\hline \multirow[t]{2}{*}{ Relationships with Supervisors } & \multicolumn{2}{|c|}{ Mean } & S.D. & Var. & \multicolumn{2}{|c|}{ Skew. } & \multicolumn{2}{|c|}{ Kurt. } & \multirow[b]{2}{*}{$\mathrm{R}$} \\
\hline & Stat. & SE & Stat. & Stat. & Stat. & SE & Stat. & SE & \\
\hline Clear Understanding of Supervisor's Expectation & 1.51 & .062 & .62 & .39 & .8 & .241 & -.2 & .478 & 1 \\
\hline Supervisor Actively Listens Suggestions & 1.86 & .056 & .56 & .32 & -.01 & 241 & -.01 & .478 & 2 \\
\hline Supervisor Enables to Perform at Best & 1.87 & .054 & .54 & .29 & -.08 & .241 & .2 & .478 & 3 \\
\hline Supervisor Promotes an Atmosphere of Teamwork & 1.91 & .049 & .49 & .24 & -.2 & .241 & 1.0 & .478 & 4 \\
\hline $\begin{array}{l}\text { Supervisor Provides Actionable Suggestions to } \\
\text { Improve }\end{array}$ & 1.98 & .056 & .56 & .32 & .3 & .241 & 1.4 & .478 & 5 \\
\hline $\begin{array}{l}\text { Supervisor Evaluates Work Performance on A } \\
\text { Regular Basis }\end{array}$ & 2.86 & .053 & .53 & .28 & -.1 & 241 & .3 & |478. & 6 \\
\hline
\end{tabular}

\begin{tabular}{|l|c|c|c|c|c|c|c|c|c|}
\hline \multirow{2}{*}{ Respect from Co-Workers } & \multicolumn{2}{|c|}{ Mean } & S.D. & Var. & \multicolumn{2}{|c|}{ Skew. } & \multicolumn{2}{|c|}{ Kurt. } & \multirow{2}{*}{ R } \\
\cline { 2 - 10 } & Stat. & SE & Stat. & Stat. & Stat. & SE & Stat. & SE & R \\
\hline Easy to Get along With Colleagues & 1.30 & .048 & .48 & .23 & 1.1 & .241 & .01 & .478 & 1 \\
\hline $\begin{array}{l}\text { Department Communicate Sufficiently With One } \\
\text { Another }\end{array}$ & 1.80 & .066 & .66 & .44 & .2 & .241 & -.7 & .478 & 2 \\
\hline High Morale in Department & 1.86 & .058 & .58 & .34 & .02 & .241 & -.1 & .478 & 3 \\
\hline Supervisor Does a Good Job & 1.92 & .058 & .58 & .33 & .00 & .241 & .00 & .478 & 4 \\
\hline
\end{tabular}

\begin{tabular}{|c|c|c|c|c|c|c|c|c|c|}
\hline \multirow{2}{*}{ Opportunity for Advancement } & \multicolumn{2}{|c|}{ Mean } & S.D. & Var. & \multicolumn{2}{|c|}{ Skew. } & \multicolumn{2}{|c|}{ Kurt. } & \multirow[b]{2}{*}{$\mathrm{R}$} \\
\hline & Stat. & SE & Stat. & Stat. & Stat. & SE & Stat. & SE & \\
\hline Necessary Training & 1.13 & .033 & .33 & .11 & 2.2 & .241 & 3.0 & .478 & 1 \\
\hline Opportunity to Learn & 1.46 & .055 & .55 & .31 & .6 & .241 & -.5 & .478 & 2 \\
\hline Opportunity to Learn New Skills & 2.12 & .057 & .57 & .32 & .6 & .241 & 1.8 & .478 & 3 \\
\hline $\begin{array}{l}\text { Support for Additional Training } \\
\text { and Education }\end{array}$ & 2.44 & .068 & .68 & .47 & .3 & .241 & -.06 & .478 & 4 \\
\hline $\begin{array}{l}\text { There is the opportunity to } \\
\text { utilize my skills and talents }\end{array}$ & 2.66 & .067 & .66 & .44 & -.09 & 241 & -.1 & .478 & 5 \\
\hline
\end{tabular}

Note: S.D.-Standard Deviation, Var.-Variance, Skew. -Skewness, Kurt.-Kurtosis, R-Rank

The table 3 is presenting the descriptive statistical result of the surveyed questionnaire regarding the perceptions of the employees' satisfaction as it is earlier stated. In the table the first main category of the result is working condition where the first ranked forces is shown relationships with the subordinates that is the mean value of 1.22 that is in between the strongly agree and agree with the standard error of 0.46 and the variance of the perceptions is seen as 0.21 , skewness 1.9 and kurtosis 0.478 followed by the other forces. The region between the somewhat agree and disagree that is 3.38 is seen in the table in the case of the forces of stress feelings by the employees followed by the forces of workload that is 2.88 . In this study reward and benefit variables are given more emphasize to measure the level of job satisfaction of the employees of the banks where the most influential forces is seen arrangement of the fringe benefits that is the mean result shows 1.60 and standard deviation of the perception is 0.56, summarily the perception of the employees regarding the arrangement of fringe benefits lies between strongly agree and agree while agree is the most dominant opinion. On the other hand, the reverse result is shown in fair opportunity for promotion of the employees that is the result lies between somewhat agree and disagree (3.03) 
with the standard deviation of 0.42 , besides these the outcome of this forces is negatively skewed. The result of the descriptive statistics in the category of relationships with supervisor showing a sound consistent regarding the question of job satisfaction of the selected banks where the most influential forces lies between strongly agree and agree mean of 1.51 with the standard deviation of 0.62 of the forces that describe regarding clear understanding of supervisor's expectation. Only a single anyhow inconsistent forces is seen that is supervisor evaluates work performance on a regular basis with the mean value of 2.86 (between agree and somewhat agree) and standard deviation of 0.053 as well negatively skewed. Respect from the co-workers category has the fits variables where most effective forces is Easy to get along with colleagues with the mean value of 1.30 and with the most consistent values while the least is 1.92. All variables are positively slewed. All of the variables are lies between the region of strongly agree and agree. Lastly, the statistical analysis of the opportunity to advancement of the employees' relation to the employees' job satisfaction shows that the most handsome value of the mean is shown as 1.13 that is necessity of training with the standard error of 0.033 and standard deviation is 0.33 . The value of the variance is only 0.11 positively skewed. Whereas the most reverse values are seen in the section of there is the opportunity to utilize my skills and talents lies between agree and somewhat agree (mean value $=2.66$, $\mathrm{SD}=0.67$ with negatively skewed and leptokurtic).

\section{Statistical Measurement of Employees' Job Satisfaction}

For measuring the aggregate level of the job satisfaction of the employees of the respective branch simple statistical tools is used where the average of the mean value and standard deviation value of the surveyed main variables of the study are taken to test the perceptions of the employees towards their job that is shown in the below table.

Table 4: Result of the Average Values

\begin{tabular}{|l|c|c|}
\hline Particulars & Average Mean Value & Average Standard Deviation Value \\
\hline Working Conditions & 2.00 & 0.52 \\
\hline Compensations and Benefits & 1.24 & 0.49 \\
\hline Relationships with Supervisors & 1.20 & 0.55 \\
\hline Respect from Co-Workers & 0.86 & 0.58 \\
\hline Opportunity for Advancement & 1.09 & 0.56 \\
\hline Average & 0.71 & 0.54 \\
\hline
\end{tabular}

Source: Table No-4.3

In the above table 4 the five main variables such as working conditions, compensations and benefits, relationships with supervisors, respect from co-workers and opportunity for advancement are taken from the table 3 . The mean values of the each forces of the table 3 are taken to measure the aggregate job satisfaction of the employees. The above table shows that the employees are exactly agreed of the working conditions of the organization with the standard deviation of 0.52 . The reward and benefits section of the study lies between the strongly agree and agree with the mean value of 1.24 and standard value of 0.49 . The most favorable perceptions from the employees come out regarding their job satisfaction is respect from co-workers. The mean value of this variable is 0.86 with the highest standard deviation of 0.58 . However, the average of the calculated mean values is 0.71 with the average standard deviation of 0.54 . That is the perceptions of the surveyed employees regarding their job satisfaction comes into strongly agree if the standard deviation will be added then the value will be 1.25 that is the perceptions lies between strongly agree and agree. Thus the statistical 
analysis is disseminating the result that the employees are satisfied with job and its various variable characteristics.

\section{Hypothesis Testing}

For testing the hypotheses of this study and report some statistical tools are used to measure the employees' job satisfaction of the employees in relation to the organizational culture. The measures are mentioned below-

Table 5: Matrix of Inter-Correlations of the Sub-Scores in Relation to Organizational Culture

\begin{tabular}{|l|l|l|l|l|l|}
\hline Independent Variables & 1 & 2 & 3 & 4 & 5 \\
\hline Working Conditions & 1 & & & & \\
\hline 2. Compensation and Benefits & 0.750 & 1 & & & \\
\hline 3. Relationships with Supervisors & 0.845 & 0.769 & 1 & & \\
\hline 4. Respect from Co-Workers & 0.810 & 0.731 & 0.813 & 1 & \\
\hline 5. Opportunity for Advancement & 0.787 & 0.741 & 0.832 & 0.814 & 1 \\
\hline
\end{tabular}

** Correlation is Significant at the 0.01 level (2-tailed)

The table 5 is used to measures the correlations among the independent variables of this study using inter-correlations matrix where the highest correlations is seen between the variables of relationships with supervisors and working conditions $(\mathrm{r}=0.845)$ at the 0.001 level of significance. On the other hand, the least value of the correlations is shown between the variables of respect from co-workers and compensation and benefits that is $r=0.731$. But all the variables are positively correlated among each other though some are highly correlated.

Table 6: Correlation between Dependent and Independent Variables

\begin{tabular}{|l|c|c|c|c|c|}
\hline Particulars & W.C & C \& B & R. S. & R. C.W & O.A. \\
\hline Rank & 5 & 4 & 3 & 1 & 2 \\
\hline Job Satisfaction & 0.701 & 0.773 & 0.795 & 0.854 & 0.811 \\
\hline
\end{tabular}

Note: W.C.-Working Conditions, C \& B. - Compensation and Benefits, R. S.-Relationships with Supervisors, R.C.W-Respect from Co-Workers, O.A.-Opportunity for Advancement ** Correlation is Significant at the 0.01 level (2-tailed)

In the table 6 shows the values of correlations between the dependent and independent variables of the study where rank is used and the first ranking variable is respects from co-workers as the independent variable is strongly correlated with the job satisfaction of the organization. The last rank is seen working conditions that have the score of $70.10 \%$. It should be remembered that all the correlations are found statistically significant at the level of 0.01 of 2-tailed z-value.

Table 7: Model Summary ${ }^{\mathrm{b}}$

\begin{tabular}{|c|c|c|c|c|}
\hline Model & $\mathrm{R}$ & R Square & Adjusted R Square & Std. Error of the Estimate \\
\hline 1 & $0.882^{\mathrm{a}}$ & 0.783 & 0.768 & 0.761 \\
\hline
\end{tabular}

a. Predictor Constant: Working Conditions, Compensation and Benefits, Relationships with Supervisors, Respect from Co-Workers, Opportunity for Advancement

b. Dependent Variable: Job Satisfaction

The above table 7 shows whether independent variables i.e. Working Conditions, Compensation and Benefits, Relationships with Supervisors, Respect from Co-Workers and Opportunity for Advancement are capable of influencing the dependent variable 'job 
satisfaction'. It is also conspicuous that the model explains as much as $76.8 \%$ of the variation of the 'job satisfaction' (adjusted $r$ square $=0.768$ ).

Table 8: Analysis of Variance (ANOVAb)

\begin{tabular}{|c|c|c|c|c|c|}
\hline Model & Sum of Square & df & Mean Square & F & Sig. \\
\hline Regression & 262.138 & 21 & 12.483 & 35.217 & $.003^{\mathrm{a}}$ \\
\hline Residual & 155.502 & 478 & 0.325 & & \\
\hline Total & & 499 & & & \\
\hline
\end{tabular}

a. Predictor Constant: Working Conditions, Compensation and Benefits, Relationships with Supervisors, Respect from Co-Workers, Opportunity for Advancement (Organizational Culture) b. Dependent Variable: Job Satisfaction

The statistical results using the values of the taken variables of organizational culture imply that Working Conditions, Compensation and Benefits, Relationships with Supervisors, Respect from Co-Workers, and Opportunity for Advancement directly affect the level of job satisfaction to increase. It is also evident from the above table that Respects from the CoWorkers has the most domination in framing 'Job Satisfaction' of the bankers and Working Conditions has the least among five explanatory variables. Based on the principle that is if pvalue is smaller than the significance level, $\mathrm{H}_{\mathrm{o}}$ is rejected; thus according to the results of the above tables and statistics, it can be able to reject the null hypothesis of the study at 0.01 level of significance, therefore, it can be concluded that the abovementioned five variables of organizational culture have the direct effect over the level of job satisfaction to either increase or decrease in relation to the employees' job perceptions and reactions.

\section{CONCLUSIONS AND RECOMmENDATIONS}

The World economy continued to develop at a rate of 2.6 percent in 2014 (World Bank; Global Economic Report). The global economy is expected to expand at a slightly faster but still only moderate pace, with world gross product projected to grow by 3.1 and 3.3 percent in 2015 and 2016 respectively (United Nations Report). As well the economy of Bangladesh is going from strength to strength. It is now well-balanced and in good shape. In such an economy, we see a paradigm shifts in Banking Industry. The organizational culture of maintaining congenial work-environment in the banks organization has further enabled the staff to benchmark themselves better against management expectations. A commitment to quality and excellence in service is the hallmark of their identity. Job satisfaction is on the top of the important targets for an establishment which is in the process of total quality because, the provision of total quality, first of all, is based on the sincere commitment to work of the corporate employees/managers and being satisfied with their jobs; namely, doing their jobs fondly. This study focuses on the employees' job satisfaction of the banks employees in Bangladesh in relation to the organization cultural perceptions and reactions. The most positive initiative of the bank organization is to inspire the female employees to be involved more to the service and economic activities of the country. In this study five variables of organization cultural related are used to measure the job satisfaction level of the employees. All variables showed the positive results that are the employees are satisfied with their jobs in their bank organizations. Some findings regarding the somewhat disagree of the employees regarding their job are mentioned with the recommendation. This study offers many different outlooks on the subject; some theorists believe that there is no correlation between the two variables while others disagree. The literature also identifies that the mentioned variables of this study play a role in job satisfaction. Organizations must motivate their employees and guarantee job satisfaction as this satisfaction is necessary to employees realizing their worth and potential; this realization subsequently will have a significant, positive impact on the efficiency and effectiveness of workers and thus, the productivity of the organization. 
Organizations need to conduct research in order to remain current on issues such as job satisfaction. It is research like this that will give them the information they desire in order to improve their companies. The usefulness of understanding the relationship between satisfaction and performance is underplayed because of its past popularity, however organizations would do well if they themselves investigate this significant relationship, as this research will have far reaching consequences not only for the organization but for the academic community as well. A further recommendation for future research would be to establish whether improving measurement and feedback mechanisms in the jobs of social workers would positively influence job satisfaction and perception of organizational culture by employees in this job category.

\section{REFERENCES}

Azad, M. R., Khan, W., \& Ahmed, A. A. A. (2011). HR Practices in Banking Sector on Perceived Employee Performance: A Case of Bangladesh. Eastern University Journal, 3(3), 30-39. https://doi.org/10.5281/zenodo.4043334

Ahmed, M. (2015). The Role of Self-esteem and Optimism in Job Satisfaction among Teachers of Private Universities in Bangladesh. Asian Business Review, 1(2), 114-120.

Ahsan, S. (2015). Corporate Culture and Organizational Change- a Study on a Large Pharmaceutical Company in Bangladesh. Asian Business Review, 4(2), 29-37.

Alam, S. (2015). Factors Affecting Job Satisfaction, Motivation and Turnover Rate of Medical Promotion Officer (MPO) in Pharmaceutical Industry: A Study Based in Khulna City. Asian Business Review, 1(2), 126-131.

Alvi, H. A. et al, 2014, Impact of Organizational Culture on Organizational Commitment and Job Satisfaction, European Journal of Business and Management, Vol.6, No.27, pp. 30-39

Armstrong, M. 2006, A Handbook of Human resource Management Practice, Tenth Edition, Kogan Page Publishing, London, p. 264

Arnold, T. \& Spell. S. C. 2006, "The Relationship between Justice and Benefits Satisfaction" Journal of Business and Psychology, Vol. 20, No. 4 page. 599620

Aziri, B. 2011, Job Satisfaction: A Literature Review, Management Research \& Practice, Vol. 3 Issue 4, pp: 3-4

Babin, B. J., \& Boles, J. S. 1996, The effects of perceived co-worker involvement and supervisor support on service provider role stress, performance and job satisfaction, Journal of Retailing, 72, 57-75

Bandura, A. 1982, Self-efficacy mechanism in human agency. American Psychologist, 37, 122- 147

Bellou. V, 2010, Organizational culture as a predictor of job satisfaction the role of gender and age," Career Development International journal" Vol 15 (1), 4- 19

Biswas, W. 2015, Impact of Organization Culture on Job Satisfaction and Corporate Performance, Journal of Research in Humanities and Social Science, Vol. 3, Issue 8 pp14-16,

Blum, M. L and Naylor, J. C. 1968, Industrial psychology: Its theoretical and social foundations. New York: Harper and Row, pp-8-12

Cole, L. E. 2012, Employee Satisfaction and Organizational Performance: A Summary of Key Findings from Applied Psychology, 5 East Towering Pines Conway, AR 72032

Cranny, C. J., et. al. 1992, Job Satisfaction: How people feel about their job and how it affects their performance, New York: Lexington Books

Davis, K. and Nestrom, J. W. 1985, Human Behavior at work: Organizational Behavior, 7 editions, McGraw Hill, New York, p.109

Drucker, P. F. 1994, Managing in turbulence time. Oxford: Butterworth-Heinemann Ltd.

George, J. M. and Jones, G. R. 2008, Understanding and Managing Organizational behavior, Fifth Edition, Pearson/Prentice Hall, New Jersey, p. 78

Grant, A. M., Christianson, M. K., Price, R. H. 2007, Happiness, Health, or Relationships? Managerial Practices and Employee Well-Being Tradeoffs, Academy of management perspectives, 21, 51-63

Greenhaus, J. H., Parasuraman, S. \& Wormley, W. M. 1990, "Race effects of organizational experience, job performance evaluation, and career outcome" Academy of Management Journal, vol 33 issue 1, page 64-96

Griffen, R. W. Text book: Management, 5th edition, published by Houghton Mifflin Company, 1997, P - 456

Hackman, J. R. and Oldham, G. R. 1975, Development of the job diagnostic survey. Journal of Applied Psychology, 60, 159-170

Hoppock, R. 1935, Job Satisfaction, Harper and Brothers, New York, p. 47 
Indermun, V. 2013, The Job Satisfaction Employee Performance Relationship: A Theoretical Perspective, International journal of Innovative Research in Management ISSN 2319 - 6912

Islam, M. M. et. al. 2013, A Study on Job Satisfaction: Focus on Bankers of Bangladesh, European Journal of Business and Management, Vol. 5, No. 17, pp. 1-7

Jiang . J. J. \& klein. G. 2000, "Supervisor Support and Career Anchor Impact on the Career Satisfaction of the EntryLevel Information Systems", Journal of Management Information Systems. Vol. 16, No. 3 page.219-240

Jung J, S. X., Baeza, M. \& Hong S. 2008, The effect of organizational culture stemming from national culture towards quality management deployment, "The TQM Journal", Vol. 20 (6), 622 - 635

Kinzl, J. F. 2005, Influence of working conditions on job satisfaction in anesthetists, British Journal of Anaesthesia 94 (2): 211-15

Kram, K. E. 1985, Mentoring at Work: Developmental Relationships in Organizational Life, page 201

Kreis, K. \& Brockopp, D. Y. 1986, Autonomy: A component of teacher job satisfaction

Latif, M. S. 2013, Impact of employee's job satisfaction on organizational performance, European Journal of Business and Management, Vol.5, No.5: 166

Locke, E. A. 1969, What is Job Satisfaction? Organizational Behavior and Human, 4, 309-336

Lund D.B, (2003), Organizational culture and job satisfaction, "Journal of Business \& Industrial Marketing", Vol. 18 (3), 219 - 236

Maslowski, R. 2001, School Culture and School Performance: An Explorative Study into the Organizational Culture of Secondary Schools and their Effects. Endschede, The Netherlands: Twente University Press

McKinnon, L. J., Harrison, L.G., Chow, W.C. and Wu, A. 2003, “Organizational culture: Association with commitment, job satisfaction, propensity to remain and information sharing in Taiwan", International Journal of Business Studies, Vol. 11 No. 1, page. 25-44

Modrak, M. M. 2011, A Theoretical Approach to the Job Satisfaction, Polish Journal of Management Studies, Vol. 4 No. 7

Mohammed, B. F. 2013, Job Satisfaction and Organizational Commitment: A Correlation Study in Bahrain, International Journal of Business, Humanities and Technology Vol.3 No.5; pp. 43

Nadarasa, T. 2013, Impact of organization culture on Job satisfaction of employees in Insurance Industry, European Journal of Business and Management, Vol.5, No.30, pp. 78-83

Naseem, A. et. al. 2011, Impact of Employee Satisfaction on Success of Organization: Relation between Customer Experience and Employee Satisfaction, International Journal of Multidisciplinary Sciences and Engineering, Vol. 2, No. 5

Nasima, M., \& Alam, N. (2015). Job Satisfaction among Female Fculties of Different Public and Private Universities in Bangladesh: A Comparative Analysis. ABC Journal Of Advanced Research, 4(1), 16-26.

Pennington, M. C., \& Riley, V. P. 1991, Measuring job satisfaction in ESL using the Job Descriptive Index. Retrieved January 25, 2006

Rahman, M., \& Islam, M. (2012). An Analytical Study on Determining Effective Factors for Recruiting Right Person.ABC Journal Of Advanced Research, 1(2), 50-56.

Rahman, M., Kamruzzaman, M., Haque, M., Mamun, M., \& Molla, M. (2015). Perceived Intensity of Stress Stressors: A Study on Commercial Bank in Bangladesh. Asian Business Review, 3(3), 40-43.

Rashid A. Z., Sambasivan. M and Abdul Rahman. A., 2004, The influence of organizational culture on attitudes toward organizational change, "The Leadership \& Organization Development Journal", Vol. 25(2), 161-179

Robbins S. and Coulter M. 2004, Management (7th ed.), New Jersey, Prentice-Hall, pp 354 -357

Schein, E. 1992, Organizational Culture and Leadership (2nd ed.). San Francisco: Jossey Bass

Schein, E. 1999, The Corporate Culture Survival Guide. San Francisco: Jossey Bass

Schein, E. 2004, Organizational Culture and Leadership. San Francisco: Jossey Bass

Terera, S. R. 2014, The Impact of Rewards on Job Satisfaction and Employee Retention, Mediterranean Journal of Social Sciences MCSER Publishing, Rome-Italy Vol 5 No 1

Thoms, P., Dose, J., \& Scott, K. 2002, Relationships between accountability, job satisfaction, and trust, Human Resource Development Quarterly, 13, 307-323

Wallach, Wllen J. 1983. Individuals and Organization: The Cultural Match. Training and Development Journal Warr, P. B. 1992, Age and occupational well-being. Psychology and Ageing, 7(1), 37-45 